\title{
RADIOLOGICAL CHARACTERISTICS OF PERIOSTEAL REACTIONS
}

\author{
Nemanja Rančić ${ }^{1}$, Aleksandar Jovanovski ${ }^{1}$, Jelena Stevanović ${ }^{1}$, Ratko Stamatović ${ }^{1}$ \\ Dejan Kostić ${ }^{1}$, Igor Sekulić ${ }^{1}$, Berislav Vekić2 ${ }^{2,3}$, Jasenka Vasić-Vilić ${ }^{1}$
}

The periosteum is a thin fibrous tissue in a form of fibro-vascular membrane which covers the outer surface of bones. On conventional radiography normal periosteum is completely invisible. The periosteum can be visualized when it is elevated by underlying pathology. Periosteal reaction can be unilateral or bilateral, or localized and generalized. Depends on how fast it takes periosteum to react, it can be divided into aggressive and non-aggressive. The role of computed tomography as superior method vs. nuclear magnetic resonance, ultrasonography or scintigraphy, has been noticed a long time ago.

Acta Medica Medianae 2020;59(1):116-124.

Key words: periosteal reaction, radiology, differential diagnose, causes

\author{
${ }^{1}$ Institute of Radiology, Military Medical Academy, Belgrade, \\ Serbia \\ 2Department of Surgery, "Dr Dragiša Mišović" Clinical Center \\ Belgrade, Serbia \\ ${ }^{3}$ University of Kragujevac, Faculty of Medical Science, \\ Kragujevac, Serbia
}

Contact: Nemanja Rancic

MMA, Crnotravska 17, 11000 Belgrade, Serbia

E-mail: nece84@hotmail.com tive potential. With aging there is a decrease in the number of the osteoblasts which leads to senile atrophy and thinning of the inner layer. The outer layer is vascularized by many branches of muscle blood vessels from attaching muscles. This way blood system nourishes the exterior of the cortex and anastomoses with bone blood vessels through Haversian system and Volkmann's canals. The periosteum (cambium) is responsible for normal lamellar bone apposition on cortical bone that grows in width (periosteal ossification) (3).

Inside of the periosteum there is a large number of endothelial pericytes (4). Perycites are cells that are in close contact with endothelial cells. In the certain circumstances, these cells may differentiate into osteoblasts; these are why these cells are considered to be important source of osteoprogenitor cells (5).

Periosteum can be visualized when it is elevated by underlying pathology (1). It takes up to ten days to three weeks for it to be visualized after the specific pathological process has begun. Through whole lifetime, periosteum can produce new bone layers and that is being used in orthopedic and maxillofacial surgery (6-8).

Inner layer of the periosteum and bones are bound together by collagen fibres called Sharpey's fibres that penetrate into bone. This location is subject to the traumatic separation followed with subperiosteal hemorrhage and hematoma (9).

Periosteal reaction is caused by anything that can irritate the bone. How it looks depends on the age of the patient, the cause, the intensity of the lesion, etc. Periosteal reaction is much more intense in childhood, because in this age periosteum is attached more loosely than in the adult age and there is less number of Sharpey's fibres which are bone growth and reparation. All of these characteristics allow the periosteum high bone regenera- 
also shorter. The more intense pathology processes give more intense periosteal reaction (9).

The aim of our work was to show radiological characteristics of periosteal reactions with images of our patients with periosteal reactions on conventional radiography, computed tomography and nuclear magnetic resonance.

\section{Types of periosteal reaction}

Periosteal reaction can be unilateral or bilateral, or it can be localized and generalised. Bilateral can occur in systemic and unilateral in localized diseases (9). The most important localized processes that can cause periosteum to react are malignancies, infections and traumas.

Depends on how fast it takes periosteum to react, it can be divided into aggressive and nonaggressive. Non-aggressive periosteal reaction can be solid single layer or multilayered, forming a solid layer of new bone adjacent to the cortex. Solid single layer type is seen in benign lesions like osteoid-osteoma, trauma, chronic osteomyelitis, etc., while multilayered type that looks like "onion skin", is seen in Ewing's sarcoma. Aggressive type occurs in processes that are acute and rapid and in malignity. It can be spiculated (hair on end), form of periosteum that is perpendicular on the outer surface of the bone (Ewing's sarcoma) or it can be divergent - sunburst (osteosarcoma). Codman's triangle is a type of the periosteal reaction that is seen in aggressive lesions such as malignity, hemorrhage and osteomyelitis. With aggressive lesions, the periosteum does not have time to ossify with shells of new bone, so only the edge of the raised periosteum will ossify. Codman's triangle is consisting of triangular elevation of the periosteum with one or more layers of new bone (9).

So, as we have seen, there are several types of periosteal reactions (Figure 1). Periosteum can be seen as: reactions:

- Nonaggressive or benign types of periosteal

- Solid smooth:

$\diamond$ Thin or single layer

$\diamond$ Thick, linear osseous deposit may be separate from or merged with the underlying bone

- Solid buttress:

$\diamond$ Thick irregular

$\diamond$ Smooth

- Septated

- Aggressive types of periosteal reactions:

- Laminated or multilayered ("Onion-skin")

- Thin, linear osseous deposits extend in a direction perpendicular to the underlying cortex

-Spiculated pattern:

$\diamond$ An irregular osseous excrescence with a spiculated contour merges with the underlying cortex (hair on end-parallel spiculated)

$\diamond A$ sunburst pattern, in which linear deposits fan out from a single focus (divergent spiculated)

$\diamond$ Sloping (velvet)

-Codman's triangle consisting of triangular elevation of the periosteum with one or more layers of new bone and

-Disorganized or complex type (10).

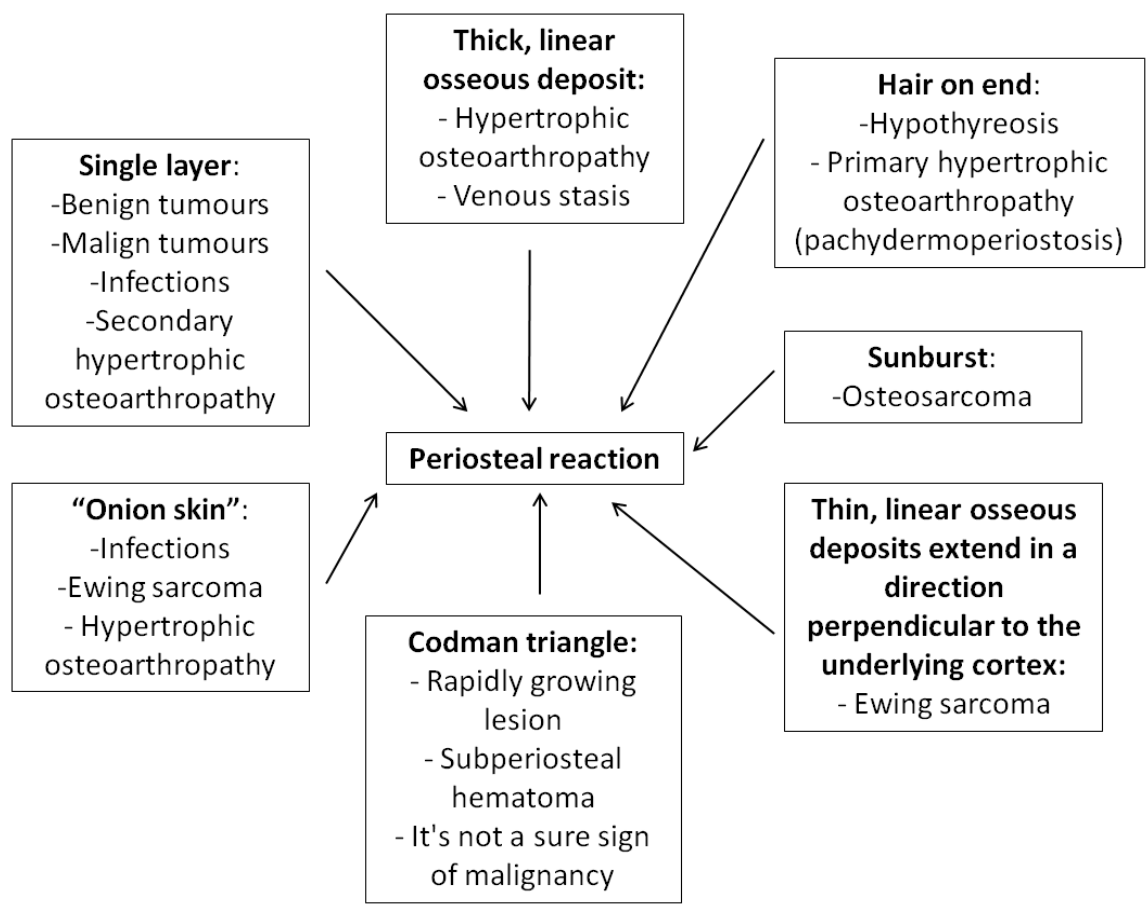

Figure 1. Differential diagnosis of periosteal reaction based on the radiographic (morphological) appearance 


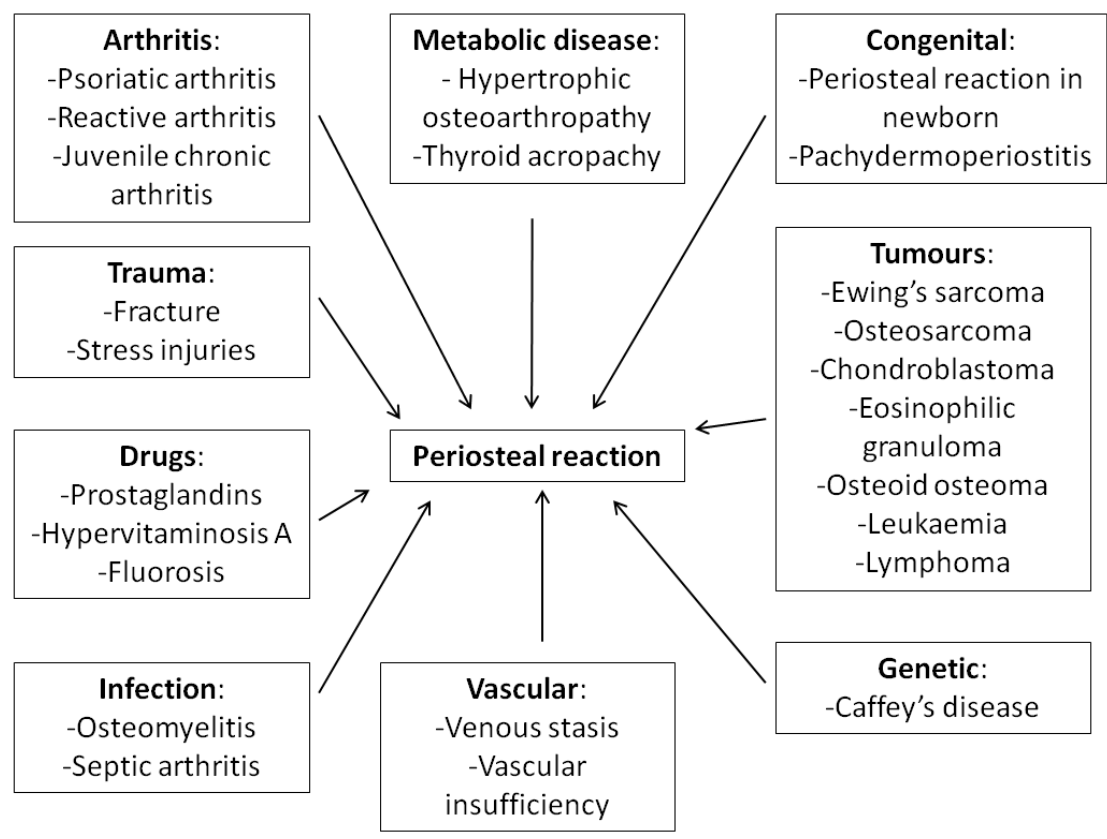

Figure 2. Differential diagnosis of periosteal reaction

\section{Causes of periosteal reaction - differential diagnoses}

There are many diseases that can cause periosteal reaction. They can be localized or systemic, or they can be hereditary and acquired (Figure 2).

Different causes irritate periosteum to react unilateral or bilateral. Unilateral reactions are seen in malignancies, infections and traumas. Bilateral are seen in adults, where they are symmetrical and are caused by hypertrophic ostheoartropathy, pachydermoperiostitis, vascular insufficiency, thyroid acropachy and abuse of fluoride. In children who are up to six months old, this type (bilateral symmetrical periosteal reaction) is seen in congenital syphilis, prostaglandin E1 therapy and Caffey's disease (infantile cortical hyperostosis). After that age (after six months old) they are symmetrical when caused by hypervitaminosis A, acute leukemia, metastatic neuroblastoma and juvenile chronic arthritis. Bilateral unsymmetrical periosteal reactions are seen in metastatic diseases, osteomyelitis, psoriatic and reactive arthritis, osteoporosis and osteomalacia, intention trauma, haemorrhagia and sickle cell dactylitis $(9,10)$.

Today as the population is getting older, many of the patients that take up to several drugs at the time in chronic therapy, there is also influence of the drugs on the periosteum (or bony tissue in general (11). Beside overdose with fluor (12) and prostaglandin $\mathrm{E} 1$, voriconazole can also cause periostitis $(10,13-17)$. Voriconazole lead to increase level of fluor in body, most often when there is kidney failure, and increased level of fluor leads to generalised periosteal reaction $(14,18)$. Risk factors for fluorosis are kidney damage, chronic abuse of voriconazole, slow metabolism of the drug and high levels of fluor in the body. All of these factors are responsible for high level of fluor - fluorosis and it causes periosteal reaction by increasing the osteoblastic activity (18).

Substance called 1,1-difluoroethane ("Dustoff") is refrigerant and aerosol propellant that can be inhaled and can, with same mechanism as voriconazole, cause generalised periosteal reaction. It also increases the level of fluor in the body. Dust-off is used for dusting the computers, key boards, photo equipment and other electronic devices, a lot of stuff for everyday use including windows, drapes, etc. Because of that, periosteal reaction in adolescents or people that have positive history of addiction can indirectly show the abuse of some substances (19).

Also, there is interleukin-11 that is thrombopoietic growth factor which stimulates production, proliferation and differentiation of megakaryoblasts into thrombocytes $(11,20)$.

\section{Image methods for periosteal reaction visualization}

Periosteum cannot be seen by conventional radiology in normal bone. Only when it is irritated by some pathological process and when there is periosteal reaction it can be observed (Figures 3-7). It takes 10 days for that to happen (21).

For diagnostic we can also use magnetic resonance imaging (MRI) and computed tomography $(C T)$, which are more sensitive for the early visualization. The MRI is superior for detecting processes in soft tissue and periosteum $(21,22)$ (Figure 8 ). Even better is CT for detecting periosteal reaction and ossification of bones $(23,24)$. The role of CT as superior method has been noticed a long time ago (23) (Figure 9). 


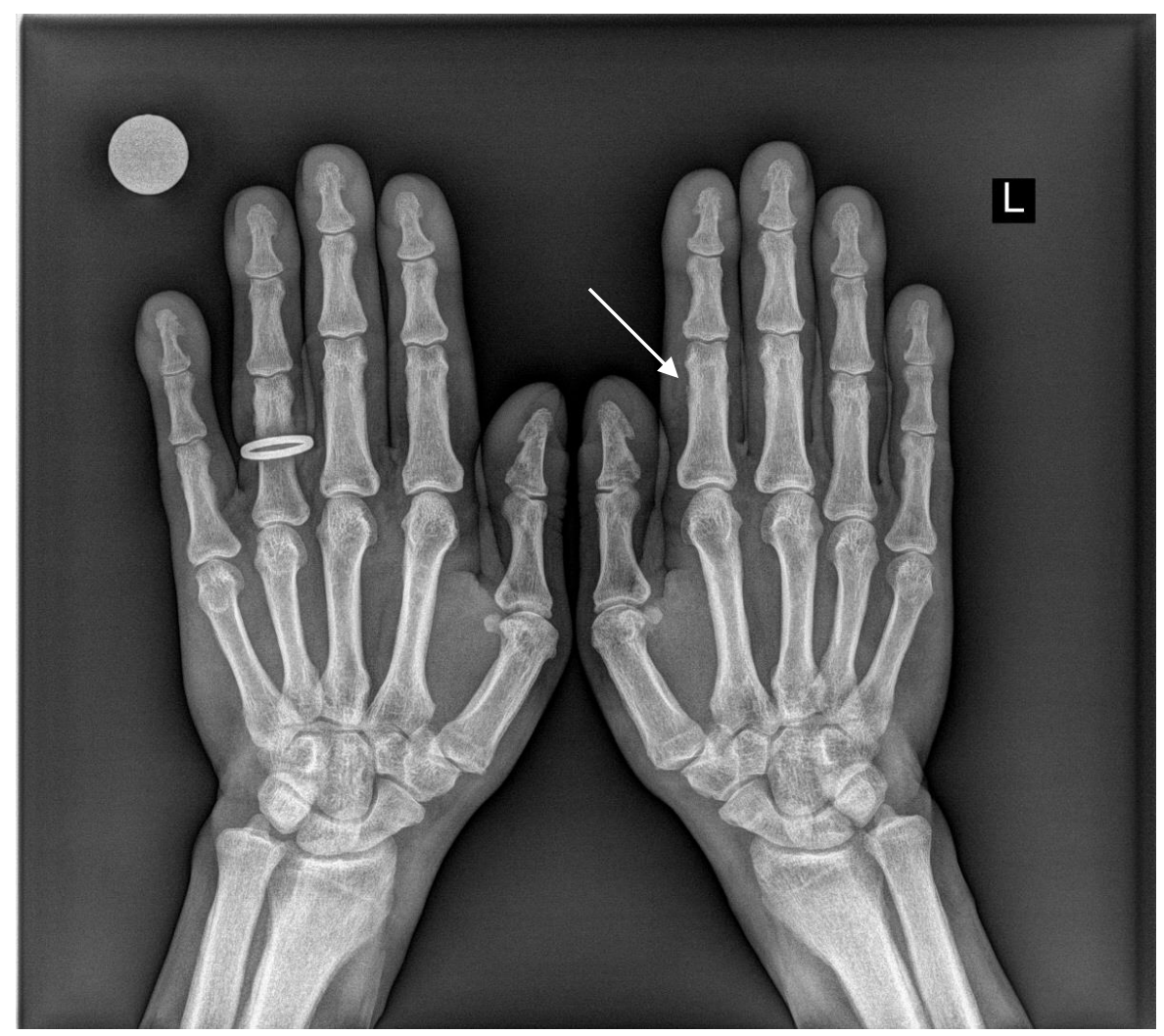

Figure 3. Left and right hand radiography at presentation show periosteal reaction involving middle and proximal phalanges of both hands in a fairly symmetric pattern - patient with hypertrophic osteoarthropathy

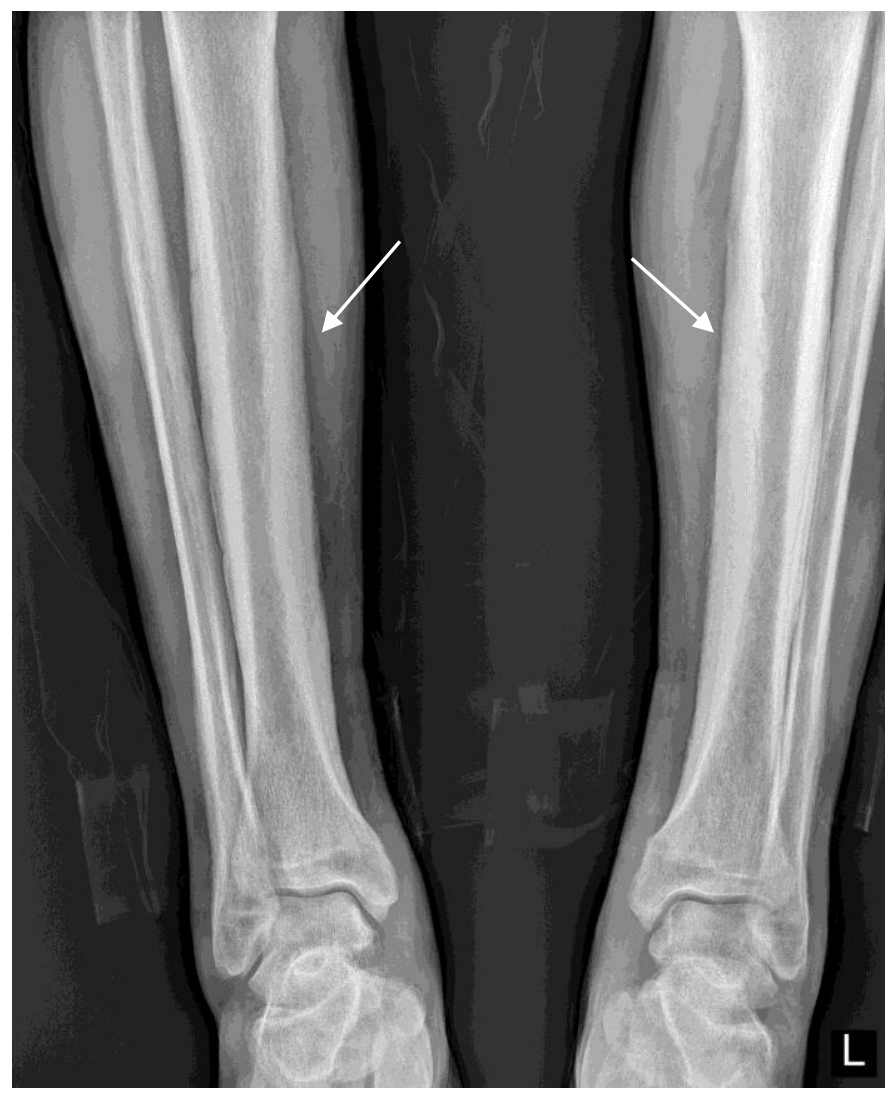

Figure 4. Left and right shin radiography at presentation show a periosteal reaction involving middle and distal diaphysis - patient with hypertrophic osteoarthropathy 


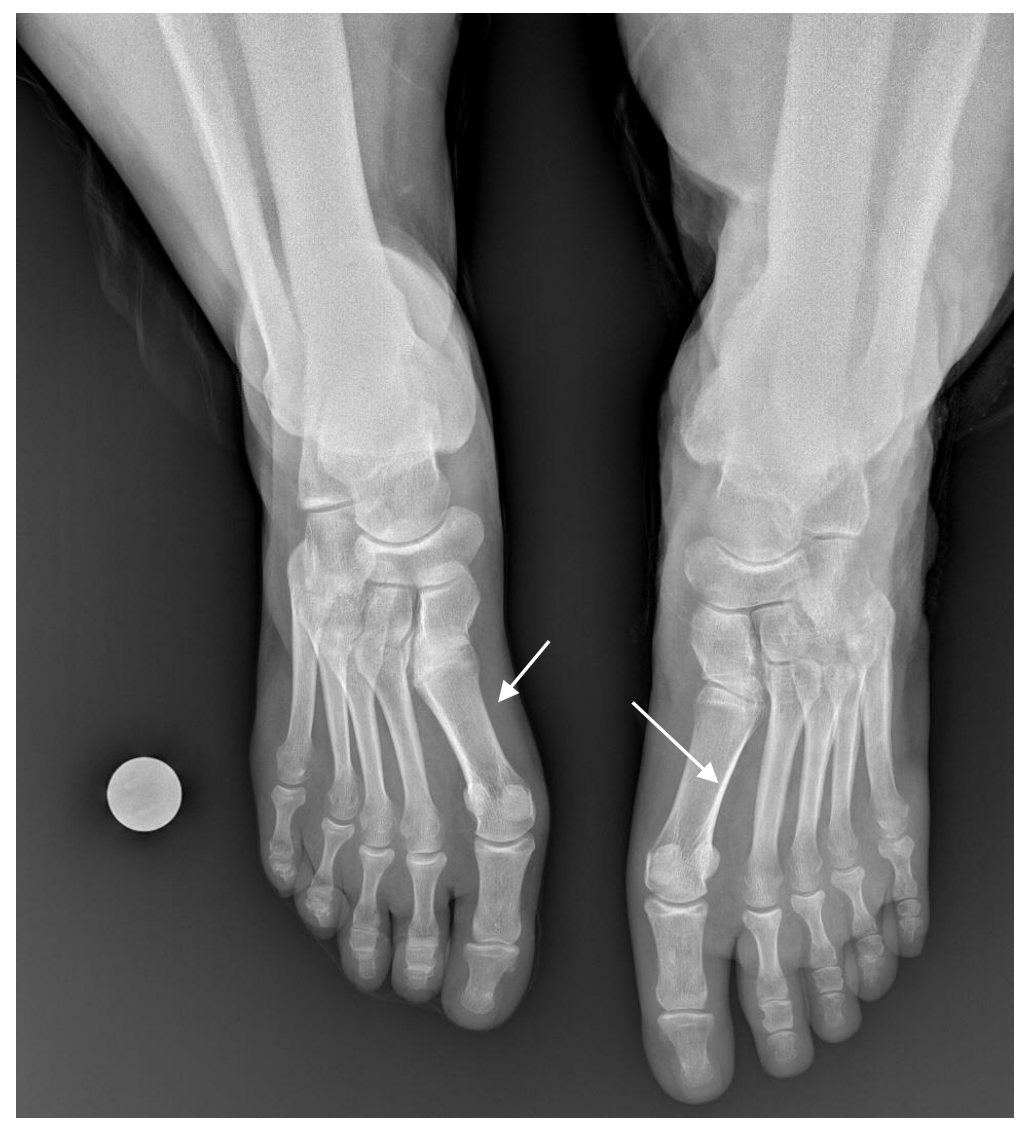

Figure 5. Left and right leg radiography at presentation show periosteal reaction involving proximal phalanges of both legs - patient with hypertrophic osteoarthropathy

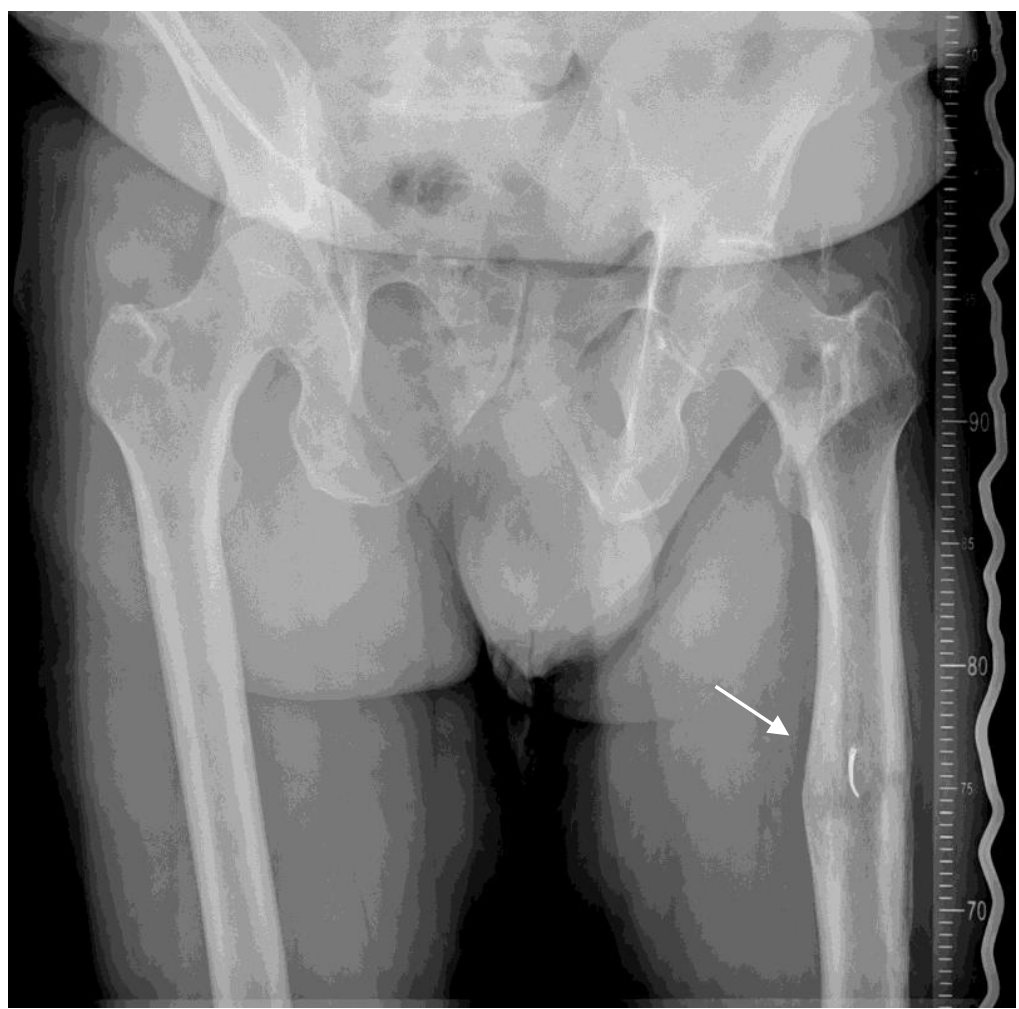

Figure 6. Left femur radiography at presentation show periosteal reaction involving middle and proximal diaphysis around the foreign body 


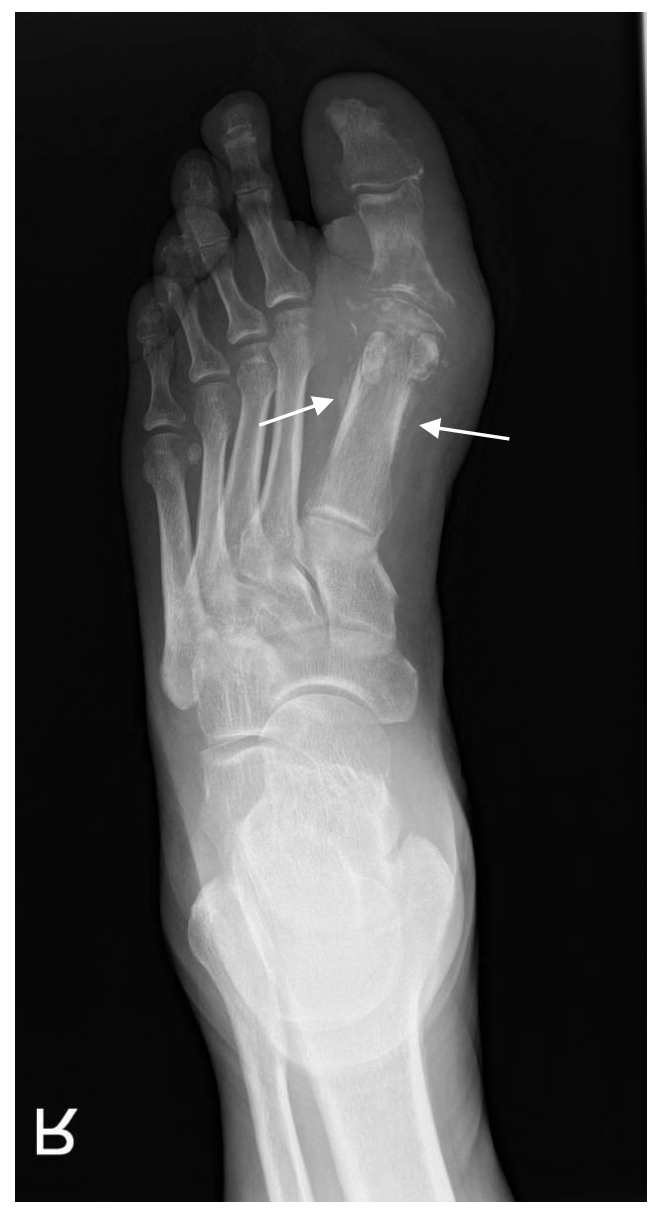

Figure 7. Right leg radiography at presentation show periosteal reaction involving first metatarsal bone after fracture and phlegmon
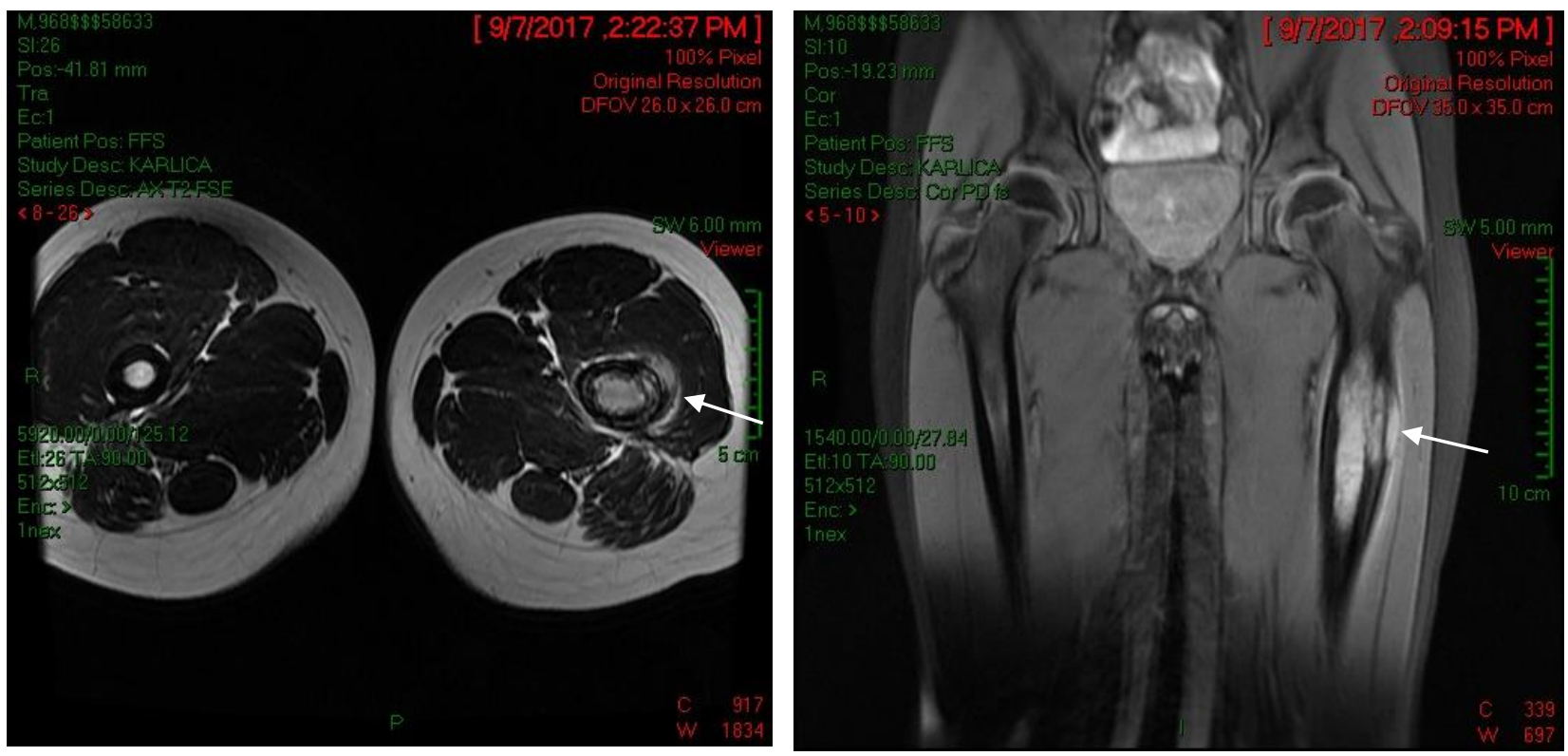

Figure 8. Left femur MRI images at presentation show periosteal reaction involving middle and proximal diaphysis around the foreign body- Ewing's sarcoma 

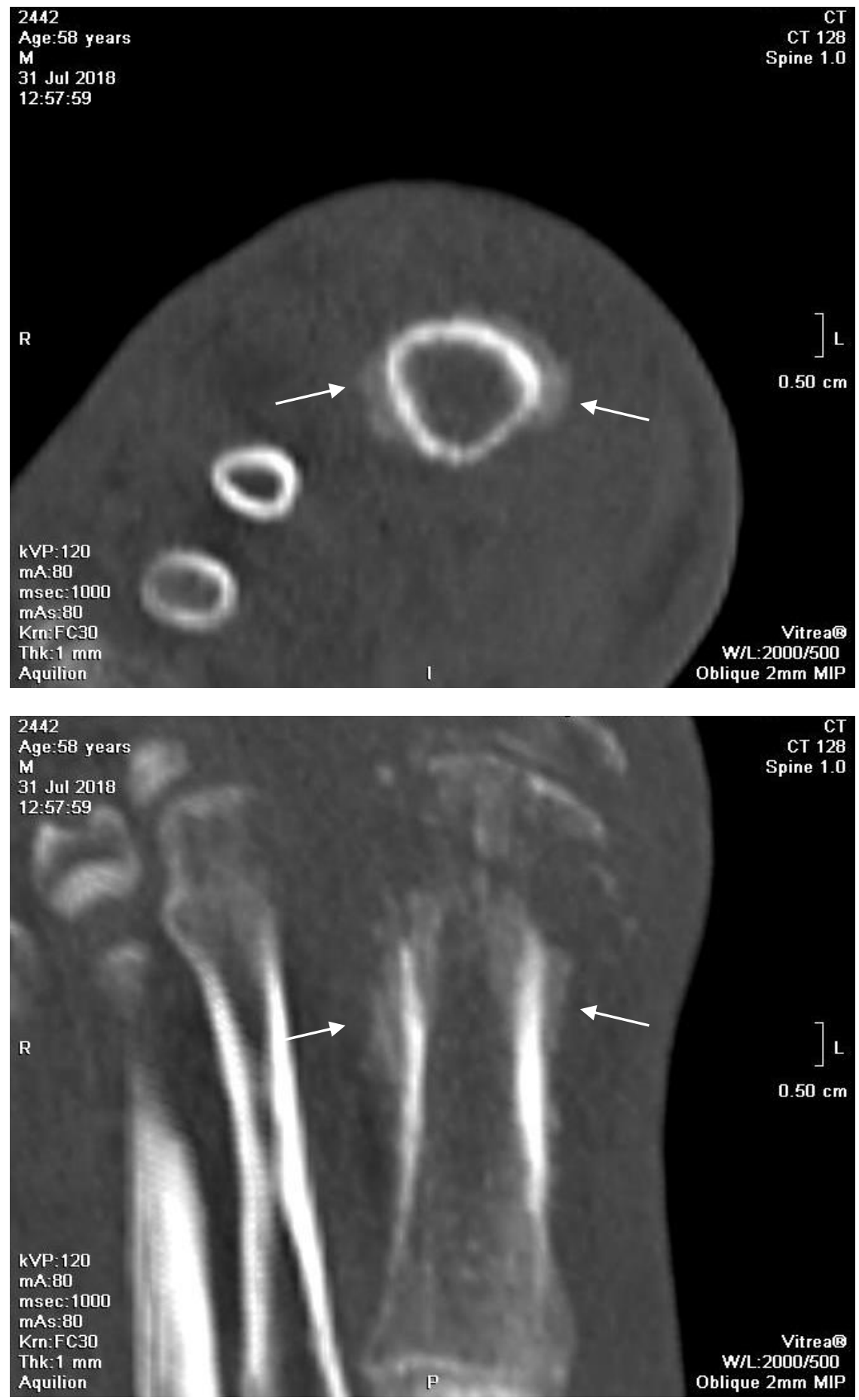

Figure 9. Right leg CT images at presentation show periosteal reaction involving first metatarsal bone (the same patient as in the Figure 7)

Ultrasonography has a minor role in visualization of the periosteum, but is used during biopsy of the changed tissue with fine needle and also is used for precise localization of these changes (21). Scintigraphy can also be used, but despite its high sensitivity it has low specificity (21). 


\section{Conclusion}

Periosteal reactions are very important in radiology diagnosis. Many localized or systemic diseases can cause periosteum to react. Because of that, general knowledge of the periosteal reactions is necessary in radiology diagnostic of the skeletal system.

\section{Conflict of Interest}

The authors declare that they have no conflict of interest.

\section{References}

1. Negovanović D. [Clinical radiology of the disease skeleton in childhood]. $2^{\text {nd }}$ edition. Belgrade: Savremena administracija; 1990. Serbian

2. Dwek JR. The periosteum: what is it, where is it, and what mimics it in its absence? Skeletal Radiol 2010; 39(4):319-23. [CrossRef] [PubMed]

3. Allen MR, Hock JM, Burr DB. Periosteum: biology, regulation, and response to osteoporosis therapies. Bone 2004;35(5):1003-12. [CrossRef] [PubMed]

4. Diaz-Flores L, Gutierrez R, Lopez-Alonso A, Gonzalez $R$, Varela $H$. Pericytes as a supplementary source of osteoblasts in periosteal osteogenesis. Clin Orthop Relat Res 1992;(275):280-6. [CrossRef] [PubMed]

5. Reilly TM, Seldes R, Luchetti W, Brighton CT. Similarities in the phenotypic expression of pericytes and bone cells. Clin Orthop Relat Res 1998;(346):95-103. [CrossRef] [PubMed]

6. Jovičić B, Lazić Z, Nedić M. [Therapeutic efficacy of guided tissue regeneration and connective tissue autotransplants with periosteum in the management of gingival recession]. Vojnosanit pregl 2008;65(10): 758-62. Serbian [CrossRef] [PubMed]

7. Lin Z, Fateh A, Salem DM, Intini G. Periosteum: biology and applications in craniofacial bone regeneration. J Dent Res 2014;93(2):109-16. [CrossRef] [PubMed]

8. de Oliveira HAAB, de Moraes RPF, Limirio PHJO, Dechichi P. Repair of a perforated sinus membrane with an autogenous periosteal graft: a study in 24 patients. Br J Oral Maxillofac Surg 2018;56(4):299303. [CrossRef] [PubMed]

9. Barlas NB, Narkhede PN, Wilkinson M, Bilal A. Periosteal reaction: a radiographic guide to disease process. European Congress of Radiology 2013; 2013 March 7-11; Vienna, Austria;2013. p. 1-21.

10. Resnick D, Kransdorf MJ. Bone and joint imaging. 3rd edition. Philadelphia: Saunders; 2004.

11. Chen L, Mulligan M. Medication induced periostitis resembling hypertrophic osteoarthropathy in lung transplant patients. European Congress of Radiology 2010; 2010 March 4-8; Vienna, Austria; 2010. p. 114.

12. Jamshidi K, Givehchian B, Mirzaei A. Florid reactive periostitis of the long bone: $A$ case series of seven patients. J Orthop Sci 2017;22(3):560-5.

[CrossRef] [PubMed]
13. Adwan MH. Voriconazole-induced periostitis: a new rheumatic disorder. Clin Rheumatol 2017;36(3):60915. [CrossRef] [PubMed]

14. Glushko T, Colmegna I. Voriconazole-induced periostitis. CMA] 2015;187(14):1075. [CrossRef] [PubMed]

15. Letts $M$, Pang $E$, Simons J. Prostaglandin-induced neonatal periostitis. J Pediatr Orthop 1994; 14(6): 809-13. [CrossRef] [PubMed]

16. Badheka A, Bangalore Prakash P, Allareddy V. Prostaglandin E1-induced periostitis and reversibility with discontinuation. J Pediatr 2017;189:237-237.e1. [CrossRef] [PubMed]

17. Oliveira-Filho IL, Rocha CT, de Menezes AKA, Bezerra MF, Neves BG. Proliferative periostitis in a pediatric patient. J Dent Child (Chic) 2018;85(1):23-7. [PubMed]

18. Gerber B, Guggenberger R, Fasler D, Nair G, Manz MG, Stussi G, et al. Reversible skeletal disease and high fluoride serum levels in hematologic patients receiving voriconazole. Blood 2012;120(12):2390-4. [CrossRef] [PubMed]

19. Hock LE, Honkanen I, Fiordellisi W, Bettendorf B. Reactive periostitis from inhalant abuse. Arthritis Rheumatol 2018;70(9):1391. [CrossRef] [PubMed]

20. Milman E, Berdon WE, Garvin JH, Cairo MS, Bessmertny O, Ruzal-Shapiro C. Periostitis secondary to interleukin-11 (Oprelvekin, Neumega). Treatment for thrombocytopenia in pediatric patients. Pediatr Radiol 2003;33(7):450-2. [CrossRef] [PubMed]

21. Wenaden $A E$, Szyszko TA, Saifuddin A. Imaging of periosteal reactions associated with focal lesions of bone. Clin Radiol 2005;60(4):439-56. [CrossRef] [PubMed]

22. Davis DL. Voriconazole-related periostitis presenting on magnetic resonance imaging. Clin Cases Miner Bone Metab 2015;12(1):78-81. [CrossRef] [PubMed]

23. Ida M, Tetsumura $A$, Kurabayashi T, Sasaki T. Periosteal new bone formation in the jaws. A computed tomographic study. Dentomaxillofac Radiol 1997; 26 (3):169-76. [CrossRef] [PubMed]

24. Kopys-Wiszniewska I. [Evaluation of images of periosteum on computed tomography in children with malignant bone tumours before and after chemotherapy]. Med Wieku Rozwoj 2008;12(1):463-76. Polish [PubMed] 
Revijalni rad

UDC: $616.71-018.44-073$

doi:10.5633/amm.2020.0117

\title{
RADIOGRAFSKE KARAKTERISTIKE PERIOSTNIH REAKCIJA
}

\author{
Nemanja Rančić ${ }^{1}$, Aleksandar Jovanovski ${ }^{1}$, Jelena Stevanović ${ }^{1}$, Ratko Stamatović ${ }^{1}$, \\ Dejan Kostić ${ }^{1}$, Igor Sekulić ${ }^{1}$, Berislav Vekić2,3, Jasenka Vasić-Vilić ${ }^{1}$ \\ ${ }^{1}$ Institut za radiologiju, Vojnomedicinska akademija, Beograd, Srbija \\ 2Odeljenje hirurgije, Klinički centar "Dr Dragiša Mišović", Beograd, Srbija \\ ${ }^{3}$ Univerzitet u Kragujevcu, Fakultet medicinskih nauka, Kragujevac, Srbija \\ Kontakt: Nemanja Rančić \\ VMA, Crnotravska 17, 11000 Beograd, Srbija \\ E-mail: nece84@hotmail.com
}

Periost je tanko fibrozno tkivo (fibro-vaskularna membrana) koje prekriva spoljašnju površinu kosti. Na klasičnoj radiografiji normalan periost potpuno je nevidljiv. Može se vizualizovati kada je nadražen nekim patološkim procesom. Periostna reakcija može biti unilateralna ili bilateralna, odnosno lokalizovana ili generalizovana. Periostne reakcije dele se, u odnosu na brzinu kojom se javljaju, na agresivne i neagresivne. Uloga kompjuterizovane tomografije, kao superiorne metode, u odnosu na nuklearnu magnetnu rezonancu, ultrasonografiju ili scintigrafiju, pokazana je ranije.

Acta Medica Medianae 2020;59(1):116-124.

Ključne reči: periostna reakcija, radiologija, diferencijalna dijagnoza, uzrok 